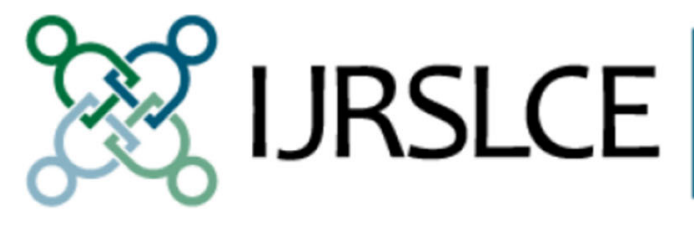

International Journal

for Research on

Service-Learning \&

Community Engagement

\title{
Indigenous Perspectives on Community Service-Learning in Higher Education: An Examination of the Kenyan Context
}

\author{
Charlene A. VanLeeuwen
}

Lori E. Weeks

Linyuan Guo-Brennan

This article was originally published at:

https://journals.sfu.ca/iarslce/index.php/journal/article/view/252/187

Recommended Citation

VanLeeuwen, C. A., Weeks, L. E., \& Guo-Brennan L. (2017). Indigenous perspectives on community service-learning in higher education: An examination of the Kenyan context. International Journal of Research on Service-Learning and Community Engagement, 5(1), 129143. 


\title{
Indigenous Perspectives on Community Service-Learning in Higher Education: An Examination of the Kenyan Context
}

\author{
Charlene A. VanLeeuwen \\ University of Prince Edward Island \\ Lori E. Weeks \\ Dalhousie University \\ Linyuan Guo-Brennan \\ University of Prince Edward Island
}

\begin{abstract}
To understand community service-learning (CSL) in global contexts, an Indigenous perspective is needed to reflect the range of contextual and historical issues. Theoretical discussions of CSL generally reference theories of experiential and reflective learning; however, work in critical pedagogy and anti-colonial discourse can be utilized to generate a framework that embraces the breadth and depth of CSL in different regions. Extant research on CSL in Africa has found that student learning and development are influenced by pressures faced by the higher education system as well as historical and contextual issues encountered by students while engaged in CSL. As discussed in this article, incorporating an Indigenous perspective within existing theoretical frameworks can enable the development of models, pedagogical approaches, and practices that reflect needs of Kenyan communities. The authors present a rationale for further CSL research in Kenya to ensure culturally sensitive, theoretically sound, and non-exploitive CSL that fosters positive outcomes for students, partner organizations, communities, and higher education institutions.
\end{abstract}

Keywords: community service-learning, Kenya, higher education, Indigenous

Community service-learning (CSL) has spread well beyond North America, and while many studies have examined this pedagogy, relatively few have explored CSL in the context of African higher education. This presents challenges for university faculty and staff wanting to utilize CSL but who are searching for literature that acknowledges and provides recommendations around contextual differences, such as higher education policy, historical and political influences, access to material resources, and local constraints within communities. Work-integrated learning opportunities such as community service-learning or practicums are widely regarded as essential components of a comprehensive undergraduate university experience and can play an important equalizing role in economic access to jobs (Universities Canada, 2016). While Giles and Eyler (1994b) noted that there are as many as 147 different terms and definitions related to CSL, we have adopted Bringle and Clayton's (2012) definition for the purposes of this article: a course or competency-based, credit-bearing educational experience in which students (a) participate in mutually identified service activities that benefit the community, and (b) reflect on the service activity in such a way as to gain further understanding of course content, a broader appreciation of the discipline, and an enhanced sense of personal values and civic responsibility. (pp. 114-115)

In this article, we synthesize current knowledge related to student experiences of CSL - first globally, then in Africa, and, finally, in Kenya. The literature reviewed focuses on students participating in local CSL opportunities (in a range of countries) rather than transnational CSL experiences, whereby a student travels to an unfamiliar community in a different country where he or she engages in CSL 
activities. We argue that in order to understand CSL in a global context such as this, researchers and practitioners must incorporate Indigenous perspectives in their work, highlighting the need for CSL experiences to remain sensitive to historical and contemporary issues, such as those resulting from colonial experiences, along with the various pressures and trends faced by the higher education system as a whole. This synthesis will be useful to university administrators, faculty and staff practitioners, and curriculum developers seeking to enhance student outcomes, to work ethically with communities, organizations, and those served by partner organizations, and to improve learning experiences for all stakeholders.

We begin with an overview of issues relevant to CSL in global higher education, followed by a discussion of the theoretical framework utilized for this article. Generally, theoretical discussions of CSL reference foundational theories of experiential and reflective learning; however, we deliberately cast the net wider to incorporate the work of scholars in critical pedagogy and anti-colonial discourse in order to generate a framework that embraces both the breadth and depth of CSL in different regions of the world. In gathering relevant literature, we determined the need to examine not only foundational research focusing on student learning and development through CSL experiences but also research literature on CSL in higher education in Africa, with a particular focus on Kenya. We include a rationale for further CSL research in Africa and Kenya, acknowledge emerging ideas about CSL in this geographic region, and identify questions for future research.

\section{Community Service-Learning in Higher Education}

The social development role of universities tasks higher education institutions with the role of preparing students not only for the workforce, but also to be active and engaged agents of change ready to tackle the multitude of issues facing society. Consequently, universities globally are being challenged to work in innovative ways with communities to address contemporary social and economic problems through curricula and learning experiences that nurture student development in various dimensions (Cloete, Bailey, Pillay, Bunting, \& Maassen, 2011; Fitzgerald, 2007; Xing \& Ka Ma, 2010).

As a philosophy, educational model, and pedagogy, CSL provides students experiential learning opportunities while they engage in tasks with community members in community settings, outside of classrooms, laboratories, practice studios, etc. (Boyer, 1996; Chambers, 2009; Clayton, Bringle, \& Hatcher, 2013; Giles \& Eyler, 1994a; Le Grange, 2007; Osman \& Castle, 2006; Whitley, 2014; Xing \& Ka Ma, 2010; Zlotkowski, 2011). Students who engage in CSL experiences achieve learning outcomes in multiple domains, including integrating theory with practice, transforming attitudes and values, taking ownership for their own learning, and developing reflective practice skills (Behar-Horenstein et al., 2016; Blouin \& Perry, 2009; Fullerton, Reitenauer, \& Kerrigan, 2015; Sharpe \& Dear, 2013; Simons et al., 2012). In addition, CSL experiences promote complexity in students' thinking, feeling, relating, and acting while enabling them to make connections among their prior learning, the social, cultural, and historical context, and the community setting (Lee \& Chen, 2014; Simons et al., 2012; Swaner, 2012; Xing \& Ka Ma, 2010). Students engaged in CSL have more opportunities to develop their relationshipbuilding skills because they are often required to maintain closer working relationships with field supervisors and partnership institutions and regularly seek their feedback on job performance (KathuriOgola et al., 2015; Preece, 2016; Sharpe \& Dear, 2013). Community service-learning has emerged as an effective pedagogical approach whose positive impacts extend beyond these promising student outcomes, with benefits extending to community members, partner organizations, educators, and other stakeholders. Universities in North American and European contexts have capitalized on the benefits of CSL opportunities for students, and CSL theories and literature in English are abundant and readily available as the result of broad-based movements in educational reform. CSL programming in other regions such as Australia, Asia, and South Africa have followed suit; however, there are some regional differences, often associated with national priorities for higher education institutions. Consequently, the theoretical perspectives that inform CSL have evolved to meet these contextual needs. As we briefly review the foundational theoretical perspectives of CSL, we extend current thinking by suggesting the application of 
additional lenses in an effort to acknowledge and enshrine Indigenous perspectives more deeply in the collective work of CSL researchers and practitioners. It is imperative, we argue, to incorporate Indigenous perspectives in CSL initiatives, starting with strong theoretical foundations.

\section{Theoretical Perspectives on Community Service-learning}

Theoretical perspectives on CSL have evolved through the contribution of a multiplicity of ideas as the service-learning movement has progressed (e.g., Boyer, 1996; Clayton et al., 2013; Cone \& Harris, 1996; Giles \& Eyler, 1994b; Permaul, 2009; Whitley, 2014). Regardless of one's perspective, most scholars and practitioners acknowledge that John Dewey set the stage for CSL by developing the concept of learning from experiences and proposing a cyclical model in which the learner reconstructs and reflects on each experience. Active, or experiential, learning is much more than "doing" and transmitting information; rather, learners learn to think by engaging in active learning and reflection (Dewey, 1933). Using Dewey's work as a foundation, Kurt Lewin (1948) integrated the concepts of social learning and problem solving into a more goal-directed learning process, which allows action (change, improvement) and learning (understanding, knowledge acquisition) to occur concurrently. David Kolb (1984) emphasized that learning comprises the creation of knowledge and meaning through active extension and grounding of ideas and experiences in the external world, accompanied by internal reflection about the attributes of these experiences and ideas. He advanced notions around a four-stage cycle of concrete experience, reflective observation, abstract conceptualization, and active experimentation. Kolb argued that for successful transformative learning to occur, the learner must complete the entire cycle - in some cases, multiple times - before learning is accomplished.

Reflective learning is a key feature of CSL, integrating theory and practice in cyclical patterns of experience and consciously applying that learning experience. Reflective learning has an important, separate meaning from experiential learning when there is no new material learned and learners reflect on what they "know" already (Moon, 2004). Recent CSL-related studies have extended reflective learning into professional studies, indicating clearly that an epistemology and capacity of professional practice based on reflection-in-action (while doing something), reflection-on-action (after you have done it), and reflection-for-action (anticipation of possible options for action planning) are defining characteristics of professional practice and important elements in preparing professionals through CSL (Boud \& Walker, 1998; Cowan, 2014; Schön, 1987). True reflective practice requires the guidance of a mentor or professional supervisor who can ask appropriate questions to ensure that the reflective process is productive and then acted upon (Schön, 1987).

Critical reflection and the pedagogy of discomfort are also important concepts in contemporary CSL literature, focusing on the empowerment of groups and communities previously excluded from formal education (Boler \& Zembylas, 2003; Freire, 1970). Through critical reflection, students can learn about themselves, develop a greater understanding of their personal strengths and limitations, and become better able to recognize and understand the political, economic, and social conditions that impact the community (Boler \& Zembylas, 2003; Freire, 1970; Mezirow, 1990). Critical reflection and praxis are informed by and situated in the lived experience of participants (Friere, 1970). Discomfort serves as an important pedagogy in CSL since it asks students to radically reevaluate their worldview, playing a significant role in teaching and learning about "difficult" issues such as racism, oppression, and social injustice (Bheekie \& van Huyssteen, 2015; Boler \& Zembylas, 2003; Zembylas, 2015).

The community service-learning literature emphasizes the importance of empowering students to challenge dominant worldviews, making space for knowledge creation in local communities that connects learning with the realities of ordinary peoples' lives and instilling a passion for social justice (Apple, 1993; Giroux, 1983). Critical approaches also serve as opportunities for students to consider "how the self is implicated in the construction of Otherness" (Giroux, 1992, p. 32). CSL with critical perspectives respects the worldviews of learners and allows more committed and informed engagement with the "learning society" and "learning organization" (Friere, 1970; Smith, 2011). In communities where members are marginalized and/or struggle with oppression and power-as a result of colonization, for 
example - students engaged in CSL are likely to be exposed to practices, attitudes, and beliefs that constrain marginalized groups in society (Brookfield, 2000; Crabtree 2008; Simmons \& Dei, 2012). Anticolonialism offers a theoretical lens through which to understand the history, politics, and education of the CSL context by interrogating the power configuration embedded in ideas, cultures, and histories of knowledge production, validation, and use (Dei \& Asgharzadeh, 2001). CSL informed by an anti-colonial framework highlights the importance of creating space for students to examine their understanding of indigeneity, pursuit of agency, resistance, and subjective politics, and to radically scrutinize both the relationship of power and possible interconnections between or among sites of oppression (Dei \& Asgharzadeh, 2001; Dreyfus, Rabinow, \& Foucault, 1983; Simmons \& Dei, 2012). As a theoretical perspective, anti-colonialism not only interrogates embedded power configurations, but it also examines one's understanding of indigeneity, pursuit of agency, resistance, and subjective politics (Dei \& Asgharzadeh, 2001; Foucault, 1983). To accomplish this, the framework works from three essential ontological premises: (1) Change is possible; (2) oppression exists but can be overcome; (3) the required tools for liberation are accessible through the mental, physical, spiritual, and emotional abilities of oppressed people (Dei, 2006). From an epistemological viewpoint, the anti-colonial framework identifies and is guided by the knowledge of the oppressed and common colonial consciousness recognizing the importance of Indigenous knowledge (Dei \& Asgharzadeh, 2001). In addition, the notion of interrogating privilege, as advanced by McIntosh (1988), is crucial to any anti-colonial approach. A consistent thread in anti-colonial discourse has been the focus on asserting humanity in light of terribly dehumanizing imperatives of colonialism related to language, the economy, and social and cultural relations (Smith, 1999).

Anti-colonial theory has significant applicability to CSL in a Kenyan context because it directs students' learning toward an examination of systems of oppression structured along lines of difference (e.g., race, class, gender, sexuality, [dis]ability, language, religion, ethnicity, etc.) and gives voice to the oppressed as a tool for accountability for the colonizer (Dei \& Asgharzadeh, 2001; Simmons \& Dei, 2012). The problems arising from colonialism are difficult (in all senses of the word), and the theoretical discourse surrounding these issues reflects this complexity. An examination of the theoretical perspectives related to CSL indicate clearly that CSL practices in global higher education connect discipline-based learning and individual identity formation and has the potential to transform inequitable conditions for self and others. Meanwhile, customization of CSL practices is imperative to ensuring that they reflect contextual differences in various locations of the world such as those related to student needs and community characteristics.

\section{Problematizing CSL Literature and Studies}

We found only a relatively small body of research examining community service-learning in the African context. A substantial quantity of African literature on CSL comprises unpublished conference presentations and reports. Thus, gathering literature in order to compare similarities and differences in North America and other colonial settings such as Canada, Australia, and India with the African context is a challenging process. The utilization of imported North American models in the South African context and comparison of North American and Africanized models of CSL have been explored in two in-depth studies (Hatcher \& Erasmus, 2008; Stanton \& Erasmus, 2013). Using the educational philosophies of Dewey (North America) and Nyerere (Africa) to better understand these models, Hatcher and Erasmus (2008) reported that both systems expected education to enable students to understand and relate to their real-world learning experiences in ways that would help to positively transform communities. CSL models and practices in both contexts are shaped by (a) calls for higher education to prepare civic-minded graduates, (b) the transformational role of higher education supported by a broad range of community stakeholders, and (c) governmental initiatives to support transformations within higher education (Hatcher \& Erasmus, 2008).

Other studies conducted by South African researchers have emphasized that students in African higher education institutions need more community-based learning opportunities to become more 
professionally confident and competent (Dorasamy \& Pillay, 2010; Ferguson \& Smith, 2011). One multidisciplinary study conducted by a group of South African researchers confirmed that skills developed through CSL contributed to deeper connections between students' theoretical knowledge and practical applications in the community (Roos et al., 2005). Context plays a significant role in students' engagement and learning; therefore, understanding the CSL context is central to students' meaningful and successful experiences (Alexander \& Khabanyane, 2013; Bheekie \& van Huyssteen, 2015; Bringle \& Hatcher, 2007) and the quality of CSL learning in relation to the longer-term goals of community engagement (Mahlomaholo \& Matobako 2006; Osman \& Castle 2006).

Examining CSL from an instructional design perspective, a comparative analysis of CSL in the United States, South Africa, and the Democratic Republic of Congo conducted by Thomson, SmithTolken, Naidoo, and Bringle (2011) stressed that educators must design effective courses, regardless of culture and context, that engage students in ways that respect local ways of knowing, practice democratic and egalitarian approaches to relationships, develop intercultural competencies, and develop efficacy for all participants. Indeed, the limited utilization of local epistemologies has been identified as a shortcoming of CSL literature and practices in African contexts (Fourie, 2003; O'Brien, 2005).

Connections with local communities are important to the success of CSL programs. There is a great need to formalize existing policies and institutional arrangements in order to facilitate meaningful community partnerships in African higher education (Henning, 1998; Linda, Mtshali, \& Engelbrecht, 2013; Naidoo \& Devnarain, 2009; Tumuti, Mule, Gecaga, \& Manguriu, 2013). Understanding the community learning context and the relationships among students, institutions, and the community is a significant step toward enabling each stakeholder in a CSL partnership to optimize his or her capital, resources, and ongoing growth (van Wyk \& Daniels, 2004). Inadequate resources, limited institutional support, and a lack of understanding of students' experiences in the CSL process have been identified as challenges to integrating CSL within higher education programs (Fourie, 2003; Mouton \& Wildshut, 2005). Another study conducted in Nigeria reported that many university graduates are unprepared for the job market because of the disconnection between the curriculum and the knowledge and skills demanded for a skilled workforce (Adeogun, Oyebade, \& Osifila, 2009). This disadvantage was confirmed by a similar comparative study of students' community engagement and service-learning at universities in the United States, the Republic of South Africa, and the Democratic Republic of Congo (Thomson et al., 2011). Thomson and colleagues (2011) concluded that in a country like the Democratic Republic of Congo-where no infrastructure exists to support the relationships among universities, students, and community organizations - the development of CSL in higher education faces significant challenges.

An assessment of internship and CSL programs at the United States International University in Nairobi indicated that students had positive attitudes about CSL opportunities, but their writing and research skills needed improvement to achieve the learning outcomes (Opiyo-Newa, 2012). In a collaborative project exploring Kenyan students and field supervisors' needs for CSL preparation, a number of challenges encountered by field supervisors were identified and reported (Kathuri-Ogola et al., 2015; VanLeeuwen et al., 2015), including helping Kenyan students to develop reflective practice skills, articulating CSL learning goals, preparing students for demanding situations and workplaces, facilitating students' development in interpersonal communication, and a lack of understanding of students' field experiences (VanLeeuwen et al., in press).

The African research studies reviewed for this article confirm that many studies on students' CSL experiences were conducted primarily in the North American context (Brownell \& Swaner, 2010; Eyler \& Giles, 1999; Zlotkowski, 1998), a concern also raised by CSL researchers and practitioners in AsiaPacific regions (Xing \& Ka Ma, 2010). CSL theoretical perspectives developed in the West and the articulation of how relationships with communities should be developed and nurtured do not fully reflect African Indigenous knowledge, wisdoms, and traditions (Fourie, 2003; Le Grange, 2007; Mahlomaholo \& Matobako, 2006; O’Brien, 2005; Osman \& Castle 2006). Additional questions regarding neo-colonial practices of using CSL models developed outside of Africa at African universities have also been put forward (Le Grange, 2007; Stanton \& Erasmus, 2013). Scholars have called for deeper inquiry into how CSL as a pedagogy is perceived by students in different cultural or political settings and how 
postsecondary education can capitalize on these differences in order to further enhance and improve student learning (Boler \& Zembylas, 2003; Thomson et al., 2011; Tonkin, 2011; Zembylas, 2015). These concerns are in addition to more general limitations identified in the current body of research, which is overrepresented by descriptive shorter-term studies and student-self reporting - that is, there are few longitudinal studies and a very limited number of published studies examining these learning experiences at universities outside of North America and Europe (Giles \& Eyler, 2013; Swaner, 2012; Whitley; 2014).

\section{Evolution of Kenyan Higher Education}

The Kenyan education system has endured many transformations as it has been used as a tool to enforce the will of colonists and the strategic directions of international development non-governmental organizations (Chege, 2009; Ndiku \& Muhavi, 2013). Over the past few decades, the higher education sector has experienced significant growth in the number of public and private institutions and student enrollment (Gudo, Olel, \& Oanda, 2011). Recent reports reveal that 443,783 students were enrolled in public and private universities in Kenya in 2014, compared to 361,379 students in 2013, which is more than double the enrolment from 2012 (ICEF Monitor, 2015). Developments that contributed to this expansion include: (1) the privatization of public universities and the establishment of new private universities; (2) pressure from political elites for regional universities; and (3) creation of open-learning centers offering programs through distance learning, articulation or twinning agreements, or credittransfer systems (Oanda \& Jowi, 2012). No other East African country has experienced such enrollment increases, placing severe strain on program quality, instructor morale, and existing infrastructure and resources (Gudo, Olel, \& Oanda, 2011; Munene, 2013). These pressures, along with reductions in funding for higher education, have led to phenomenal expansion of Kenyan university programs, serious overcrowding, and inadequate infrastructure (ICEF Monitor, 2015; Nyangau, 2014).

Faced with the exponential growth of universities, Kenya's Commission for University Education ordered universities to concentrate on offering degree programs, to ensure the ongoing quality of higher education programs (Nganga, 2011; Waruru, 2015). It is anticipated that this re-focus will result in not only a shift in student population, since approximately one third of Kenyan university students are enrolled in diploma programs, but also a reduction in the tuition revenue paid by these privately funded students (World University News, 2015). This raises questions about whether these initiatives are truly academic niches for community development or just another form of economic exploitation (Oanda \& Jowi, 2012). This initiative is still in its emergent stages, so further inquiry and evaluation are desirable to assure that expansion and concentration on degree programs are meeting local social development needs, in addition to serving as a means of revenue generation for universities.

The public perception that higher education quality is being compromised in the effort to expand enrollment has led to questions regarding the future of higher education in Kenya, its role as a repository of knowledge, and its contribution to national prosperity (Odhiambo, 2014). Researchers have joined this call to address the quality of postsecondary education (Amutabi, 2003; Magutu, Mbeche, Nyaoga, Nyaanga, \& Ombato, 2010). Consideration of these influences, which concern the national government as well as international development and non-governmental organizations that provide substantial funding for higher education, will serve as critical cornerstones in designing future research around CSL (Ndiku \& Muhavi, 2013).

Indigenization of curricula has become a high priority for nations such as Canada and Australia as they pursue reconciliation with their Indigenous communities (Commonwealth of Australia, 2008; Truth and Reconciliation Commission, 2015). While structures for embedding Indigenous perspectives within higher education are relatively recent, Thaman's (2003) work serves as a model. More recently, Universities Australia (2012) developed a five-point best-practice framework for Indigenous cultural competency in Australian universities. Canadian universities have also embarked on initiatives to enhance broader understanding of Indigenous worldviews within the academy and to extend opportunities to indigenize curricula through responsive and respectful pedagogies (Universities Canada, 2015). 
In Kenya, efforts to indigenize formal education have also taken root in part through the promotion of education through sustainable development (Dei, 2000; Owuor, 2007). However, with a secondary-school system modeled on the Cambridge Examination of the United Kingdom, there are continued foreign assumptions about what constitutes valid knowledge, which have made the integration of Kenyan Indigenous knowledge into the curriculum a challenge and, some say, superficial (Owuor, 2007). In addition, the acculturation of Eurocentric values by some Kenyans, referred to as elites by some scholars, has also added to the dilemmas and lack of consensus encountered by education system stakeholders. Finally, there is a dominant belief that prosperity is synonymous with Western development (Mwenda, 2003). Given these circumstances, it is little wonder that higher education faces similar contradictions. Integrating complex Indigenous and Western knowledges into higher education curricula is destabilizing as the power, authority and prestige of Western knowledge is challenged (Owuor, 2007).

\section{The Need for Indigenous Perspectives on CSL in Kenya}

Community service-learning can serve as an excellent strategy for re-examining the public purposes of higher education and institutional change that universities can use to fulfill their mission visà-vis service and development (Bringle \& Hatcher, 2007; O'Brien 2005). The growing expectation that universities should focus on more than student learning can lead to a cascade of positive impacts on the health and economic well-being of (Kenyan) society as these institutions support global development goals and the communities around them by becoming citadels not silos (MacGregor \& Makoni, 2010; Mulongo, 2013). Powerful pedagogical approaches, such as CSL, that address issues of power associated with gender inequities, language use, traditional knowledge, and sustainable development, can foster deep student learning that supports the civic mandate of universities in a robust and ethically sound manner. We know that approaches like these allow students to recognize their limited previous understanding of issues affecting Indigenous communities and, in many instances, their own complicity in writing off such concerns as unimportant or inconsequential (Bartleet et al., 2014). These arguments make a strong case for including Indigenous perspectives in the development of CSL experiences and as part of theoretical frameworks for CSL research, but how does this work when making choices in a particular setting? Applying this question to the Kenyan context, we offer some further contextual considerations regarding power, indigenous languages, and gender inequity.

Kenya is still dealing with the deep scars left by colonialism; these are especially evident in the extreme inequities found in Kenyan society. One example of the lingering influence of colonialism stems from language policies during the colonial era, which served as a means to dominate and control, and which introduced a more individualistic Eurocentric value system that was alien to African communal mores (Dei, 2000; Elabor-Idemudia, 2000; Woolman, 2001). The addition of this perspective to the patrilineal orientation of traditional Kenyan society resulted in the evolution of government policies that eroded and devalued Indigenous practices and languages.

Many of these policies placed girls and women at a disadvantage, leading to severe gender inequities. In many regions of Kenya, girls and young women have faced greater challenges in comparison to boys and are more likely to leave school if funds are limited, help is needed at home, they engage in child labor, or marry early (Njue, Rombo \& Ngige, 2007). This trend has changed in recent years to the point where these challenges have become more concentrated in rural areas. In addition, following strong empowerment efforts nationwide, academics who follow such developments have recorded anecdotal reports that the boy-child is being sidelined and is lagging behind (Kathuri-Ogola, personal communication, October 2017). Changes in traditional gender relations as a consequence of massive out-migration from rural communities, education and occupational trends, medical and reproductive health care, and child marriage for girls have not eliminated gender-related challenges associated with the ravaging impact of HIV/AIDS, the high prevalence of family violence, or inheritance laws for women (Elabor-Idemudia, 2000; Greiner \& Sakdapolrak, 2012; Kabaria Muriithi, 2014; Meda, 2013; Nathani Wane, 2000; Trask, 2015; UNAIDS, 2009; Wiesmann, Kiteme, \& Mwangi, 2014). While not a panacea that can redress these issues of power and equitable access to quality education for all at all 
levels, postsecondary education is one environment in which these challenges can be tackled. Investments in higher education have been identified as critical to reaching targets established by the United Nation's Sustainable Development Goals, especially goals 4 and 5, which are associated with quality education and gender equality (United Nations, 2015). Initiatives related to poverty eradication, education for all, and promotion of gender equality can all be impacted through the social development role served by universities, with postsecondary education identified as a critical element in reducing inequalities for girls and women in countries such as Kenya (Escrigas, Polak, \& Jegede, 2011; Global University Network for Innovation (GUNi), 2008, UNESCO \& UNICEF, 2013). The Kenyan government has acknowledged that the gender gap in public university student enrolment is an issue requiring urgent attention (Mulongo, 2013). Universities have been encouraged to make investments that address the severe inequities in access to higher education for women, students from disadvantaged rural areas, and/or impoverished families (Mulongo, 2013; Ochieng, 2014).

Consideration of Indigenous perspectives for CSL in Kenya must include discussion of issues around language use, since language of instruction is closely associated with worldviews, curriculum, pedagogy, and community contexts. The privileging of Eurocentric worldviews, languages, and instructional practices of former colonizers has rendered the Indigenous background of students less relevant within their varied educational contexts and has weakened their cultural identity - effects which have lingered for decades, well into the new millennium (Achebe, 1975; Breidlid, 2013; Lebakeng, 2010; wa Thiong'o, 1981). As Indigenous knowledges are produced in specific historical and cultural contexts - which encompass worldviews, cultural values and traditional practices - many challenges must be confronted by all in order for Indigenous and Western knowledge systems to coexist in a manner which is sustainable for the long-term (Breidlid, 2013; Lebakeng, 2010; Semali, 1999; Smith, 1999, 2014). By fostering awareness of the value of Indigenous knowledges that can be balanced with Western knowledges, Kenyans would be able to realize alternative solutions to some of the most pressing issues described earlier (Owuor, 2007). Curriculum development that incorporates Indigenous perspectives is not always one of the highest priorities for higher education reform when faced with critical demands for infrastructure as enrollment numbers remain high. Nevertheless, educational models, curricula, instructional practices, and learning materials that do not incorporate and respect Indigenous perspectives and contexts may not meet student, community, and societal needs effectively.

Best practices for CSL that are contextualized can provide critical insights for Kenyan higher education. However, research-based evidence to foster their formation is largely absent, pointing to huge gaps in the development of Kenyan higher education curriculum and best practices for CSL. Broad system-wide principles, such as those used in Australia and Canada, promoting the inclusion of indigenous theoretical perspectives in HE and CSL is one approach that we hope will eventually generate progressive pedagogical advances and research for CSL in Kenyan universities.

Without such perspectives and local best practices, the power of CSL is not only diminished, but there is also significant likelihood that highly negative and unquestioned worldviews, values, assumptions, and norms of relatively privileged higher education students (as individuals who have been successful in gaining access to postsecondary education) are reinforced during the CSL experience (McMillan \& Stanton, 2014). As educators and CSL practitioners in the $21^{\text {st }}$ century, pairing Indigenous perspectives and a critical approach alongside the commonly used experiential and reflective learning theories is imperative if students are to engage in meaningful CSL experiences. In the meantime, serious challenges remain with very little CSL literature providing an Indigenous perspective that acknowledges historical and social contexts (Bartleet et al., 2014; Xing \& Ka Ma, 2010). When we consider this alongside calls for universities to deepen commitments that address human needs by working in collaboration with students, communities, and community organizations to tackle and resolve social problems (Fourie, 2003; Mugabe, 2015), development of CSL experiences for HE students has the potential to provide substantive contributions. 


\section{Recommendations for Future CSL Directions}

Much of what is known about CSL comes from contexts outside of Africa; thus, the Kenyan perspective remains, in large part, an untold narrative. This is the situation regarding CSL in other regions, where university students engage in CSL without the benefit of research that accounts for important Indigenous issues. Addressing this gap is essential in order that further curricular initiatives can be based in good practice and sound evidence, contributing to deeper understanding of CSL experiences of postsecondary students globally. CSL is a pedagogy that can be effective in mediating some of the negative impacts of colonization, language, cultural considerations, and gender inequity issues. The foundational theories associated with reflective and experiential learning resonate with the social justice, critical reflective pedagogy, and anti-colonization frameworks that have informed this discussion. A pilot study or deeper exploration of Indigenous perspectives regarding CSL would be worthwhile to further develop these ideas.

As efforts to improve higher education in Kenya continue, faculty involved in CSL curriculum development may need to adapt existing theoretical frameworks to develop models and pedagogical approaches and best practices to support and extend student learning in these contexts. This could mean re-examining the theoretical frameworks currently in play and adding an anti-colonial lens. There is a rich literature on reflective practice, with many scholars promoting the practice of journaling (e.g., Boud \& Walker, 1998; Cowan, 2014; Moon 2004). In consideration of oral Indigenous traditions, alternatives to written reflective journals such as arts-based reflections (Newton \& Plummer, 2009) or collaborative efforts with community members using photo-voice or audio-recorded entries using smartphone technology just scratch the surface of possibilities. Regardless of the frameworks and practices utilized, they need to be sensitive to the different contextual circumstances. The social issues encountered by students while engaged in CSL in Africa are distinctive in many ways, and there must be congruence between the needs and wishes of families, local communities, and human service agencies and the service provided by students. Further research to develop and document best CSL practices that are responsive to the Kenyan context is needed.

Finally, institutional support for CSL initiatives that extends beyond material resources and logistical support is needed. This could include embracing CSL as part of the university's mission or strategic//academic plan, sponsoring professional development opportunities that encourage faculty to develop CSL courses, acknowledgement of the time and effort these experiences demand in tenure and promotion processes, promotion of pedagogical and administrative practices that complement rather than hinder student learning in CSL courses, and embracing commitments to forge stronger connections with its community and non-academic world for the betterment of the (local) community and society, to list just a few possibilities. Faculty engaged in CSL must be aware of and sensitive to the myriad contextual differences that can impact students' CSL experiences to ensure that the CSL activities that students are involved in are culturally competent, theoretically sound, and non-exploitive of the partner organizations and communities.

\section{Conclusion}

It is crucial for new CSL research, conducted in all regions of the world, to bring together solid theoretical foundations with existing knowledge of local contextual factors on the evolution of postsecondary CSL programs and the compelling forces and tensions within which contemporary university programs operate. Scholars and practitioners know that effective CSL experiences engage students to respect local ways of knowing, practice democratic and egalitarian approaches to relationships, and foster intercultural competencies (Thomson et al., 2011; Xing \& Ka Ma, 2010). Student preparation and growth in multiple dimensions can be supported so they gain deep insights and learning from meaningful CSL experiences, in ways that still support vulnerable communities. Sound theoretical foundations that draw on thinking from education, critical theory, and social justice to support a solid knowledge base of contextualized best practices are essential to supporting innovative developments for CSL programs that respect and reflect Indigenous perspectives. 


\section{Author Note}

Charlene A. VanLeeuwen, Faculty of Education, University of Prince Edward Island; Lori E. Weeks, Faculty of Health Professions, Dalhousie University; Linyuan Guo-Brennan, Faculty of Education, University of Prince Edward Island.

The authors wish to acknowledge the contributions of Dr. Lucy Kathuri-Ogola from Kenyatta University in Nairobi, Kenya.

Correspondence regarding this article should be addressed to Charlene VanLeeuwen, Faculty of

Education, University of Prince Edward Island, Charlottetown, PE, Canada C1A 4P3. E-mail:

cvanleeuwen@upei.ca

\section{References}

Achebe, C. (1975). Morning yet on creation day. New York: Doubleday.

Adeogun, A. A., Oyebade, S. A., Osifila, G. I. (2009). Higher education and youth preparation for the labour market: The case of universities. Makerere Journal of Higher Education, 2(1), 97-107.

Alexander, G., \& Khabanyane, M. (2013). Service learning as a response to community/school engagement: Towards a pedagogy of engagement. Perspectives in Education, 31(2), 102-113.

Amutabi, M. N. (2003). Political interference in the running of education in post- independence Kenya: A critical retrospection. International Journal of Educational Development, 23, 127-144.

Apple, M. W., (1993). Official knowledge: Democratic education in a conservative age. New York: Routledge.

Bartleet, B-L., Bennett, D., Marsh, K., Power, A., \& Sunderland, N. (2014). Reconciliation and transformation through mutual learning: Outlining a framework for arts-based service learning with Indigenous communities in Australia. International Journal of Education \& the Arts, 15(8). Retrieved from http://www.ijea.org/v15n8/

Behar-Horenstein, L., Isaac, N., Southwell, C. N., Hudson-Vassell, M., Niu, L., Pratto, M., Roberts, K. W., Wingfield, R.,Wolfgang, J., Zafar, M. A. (2016). Promoting academic socialization through service learning experiences. International Journal of Teaching and Learning in Higher Education, 28(2), 158-167.

Bheekie, A., \& van Huyssteen, M. (2015). Be mindful of your discomfort: An approach to contextualized learning. International Journal of Research on Service-Learning and Community Engagement, 3(1). Retrieved from http://journals.sfu.ca/iarslce/index.php/ journal/article/view/129/79

Blouin, D. D. \& Perry, E. M. (2009). Whom does service learning really serve? Community-based organizations' perspectives on service learning. Teaching Sociology, 37(2), 120-135.

Boler, M. \& M. Zembylas. (2003). Discomforting truths: The emotional terrain of understanding difference. In P. Trifonas (Ed.), Pedagogies of difference: Rethinking education for social change (pp. 110-136). New York: Routledge Falmer.

Boud, D., \& Walker, D. (1998). Promoting reflection in professional courses: The challenge of context. Studies in Higher Education, 23(2), 191-206.

Breidlid, A. (2013). Education, Indigenous knowledges and development in the global South: Contesting knowledges for a sustainable future. New York: Routledge.

Bringle, R. G., \& Clayton, P. H. (2012). Civic education through service learning: What, how and why? In L. McIlraith, A. Lyons, \& R. Munck (Eds.), Higher education and civic engagement: Comparative perspectives (pp. 101-124). New York: Palgrave Macmillan.

Bringle, R. G., \& Hatcher, J. A. (2007). Civic engagement and service learning: Implications for higher education in America and South Africa. Education as Change, 11(3) 79-89.

Brownell, J. E., \& Swaner, L. E. (2010). Five high-impact practices: Research on learning outcomes, completion, and quality. Washington, DC: Association of American Colleges and Universities.

Chambers, T. (2009). A continuum of approaches to service-learning within Canadian post-secondary education. Canadian Journal of Higher Education, 39(2), 77-100. 
Chege, M. (2009). The politics of education in Kenyan universities: A call for a paradigm shift. African Studies Review, 52(3), 55-71. doi:10.1353/arw.0.0231

Clayton, P. H., Bringle, R. G., \& Hatcher, J. A. (Eds.). (2013). Research on service learning: Conceptual frameworks and assessment. Vols. $2 A \& 2 B$. Arlington, VA: Stylus.

Cloete, N., Bailey, T., Pillay, P., Bunting, I., \& Maassen, P. (2011). Universities and economic development in Africa. Wynberg, South Africa: Centre for Higher Education Transformation.

Commonwealth of Australia. (2008). Apology to Australia's Indigenous peoples. Retrieved from: http://www.australia.gov.au/about-australia/our-country/our-people/apology-to-australiasindigenous-peoples

Cone, D., \& Harris, S. (1996). Service-learning practice: A theoretical framework. Michigan Journal of Community Service Learning, 3(1), 31-43.

Cowan, J. (2014). Noteworthy matters for attention in reflective journal writing. Active Learning in Higher Education, 15(1), 53-64.

Crabtree, R. (2008). Theoretical foundations for international service-learning. Michigan Journal of Community Service Learning, 15(1), 18-36.

Dei, G. J. S (2000). African development: The relevance and implications of indigenousness. In G. Dei, B. Hall, \& D. Rosenberg (Eds.), Indigenous knowledges in global contexts: Multiple readings of our world (pp. 70-86). Toronto: University of Toronto Press.

Dei, G. J. S. (2006). Mapping the terrain: Towards a new politics of resistance. In G. Dei \& A. Kempf (Eds.), Anti-colonialism and education: The politics of resistance (pp. 1-23). Rotterdam: Sense Publishers.

Dei, G. J. S. (2012). Indigenous anti-colonial knowledge as "heritage knowledge" for promoting Black/African education in diasporic contexts. Decolonization: Indigeneity, Education and Society. 1(1), 102-119. Retrieved from http://www.decolonization.org/index.php/ des/article/view/18631

Dei, G. J. S., \& Asgharzadeh, A. (2001). The power of social theory: The anti-colonial discursive framework. Journal of Educational Thought (JET) / Revue De La Pensée Éducative, 35(3), $297-$ 323. Retrieved from http://www.jstor.org/stable/23767242

Dewey, J. (1933). How we think. Retrieved from http://www.gutenberg.org/files/37423/37423-h/37423h.htm

Dorasamy, N., \& Pillay, S. (2010). Advocating service learning for developing citizenship in university students in South Africa. Industry and Higher Education, 24(4), 287-296.

Dreyfus, H. L., Rabinow, P., \& Foucault, M. (1983). Michel Foucault: Beyond structuralism and hermeneutics. Chicago: University of Chicago Press.

Elabor-Idemudia, P. (2000). The retention of knowledge of folkways as a basis for resistance. In G. Dei, B. Hall, \& D. Rosenberg (Eds.), Indigenous knowledges in global contexts: Multiple readings of our world (pp.102-119). Toronto: University of Toronto Press.

Escrigas, C., Polak, E. E., \& Jegede, O. (2011). The promotion of sustainable development by higher education institutions in Sub-Saharan Africa: Survey report. Global University Network for Innovation (GUNi), International Association of Universities (IAU), Association of African Universities (AAU). Retrieved from http://www.iauhesd.net/sites/default/files/documents/promotion_sd by heis_sub_saharan_africa.pdf

Eyler, J., \& Giles, D. (1999). Where's the learning in service learning? San Francisco: Jossey-Bass.

Ferguson, I., \& Smith L. (2011). Education for change: Student placements in campaigning organizations and social movements. South Africa British Journal of Social Work, 42, 9741994. doi:10.1093/bjsw/bcr143

Fitzgerald, H. (2007). Creating a new kind of university: Institutionalising community-university engagement. Review of Higher Education 30(2), 203-205. doi:10.1353/rhe.2006.0068

Freire, P. (1970). Pedagogy of the oppressed. New York: Continuum. 
Fullerton, A., Reitenauer, V. L., \& Kerrigan, S. M. (2015). A grateful recollecting: A qualitative study of the long-term impact of service-learning on graduates. Journal of Higher Education Outreach and Engagement, $19(2), 65-92$.

Giles, Jr., D. E., \& Eyler, J. (1994a). The impact of a college community service laboratory on students' personal, social, and cognitive outcomes. Journal of Adolescence, 17, 327-339.

Giles, Jr., D. E., \& Eyler, J. (1994b). The theoretical roots of service-learning in John Dewey: Toward a theory of service-learning. Michigan Journal of Community Service Learning 1(1), 77-85.

Giles Jr., D. E., \& Eyler, J. (2013). The endless quest for scholarly respectability in service-learning research. Michigan Journal of Community Service Learning, 20(1), 53-64.

Giroux, H. (1983). Theory and resistance in education. Westport, CT: Bergin and Garvey.

Giroux, H. (1992). Post-colonial ruptures and democratic possibilities: Multiculturalism as anti-racist pedagogy. Cultural Critique, 21, 5-39.

Greiner, C., \& Sakdapolrak. P. (2012). Rural-urban migration, agrarian change, and the environment in Kenya: A critical review of the literature. Population and Environment, 34(4), 524-553. doi:10.1007/s11111-012-0178-0

Gudo, C.O., Olel, M. A., \& Oanda, I. O. (2011). University expansion in Kenya and issues of quality education: Challenges and opportunity. International Journal of Business and Social Science, 2(20), 203-214.

Hatcher, J. A., \& Erasmus, M. A. (2008). Service-learning in the United States and South Africa: A comparative analysis informed by John Dewey and Julius Nyerere. Michigan Journal of Community Service Learning, 15(1), 49-61. Retrieved from http://hdl.handle.net/1805/4585

Henning, E. (1998). Service learning in the university curriculum: Partnerships in community education. South African Journal of Higher Education, 12(1), 44-53.

ICEF Monitor. (2015, June 1). Governments and educators in Kenya struggling to keep pace with demand for higher education. Retrieved from http://monitor.icef.com/2015/06 /governments-and-educators-in-kenya-struggling-to-keep-pace-with-demand-for-highereducation/

Kathuri-Ogola, L., VanLeeuwen, C., Kabaria-Muriithi, J., Weeks, L. E., Kieru, J., \& Ndayala, P. (2015). Supervision challenges encountered during Kenyan university students' practicum attachment. Journal of Education and Practice, 6(17) 111-117. Retrieved from http://iiste.org/Journals/index.php/JEP/article/view/23596

Kolb, D. (1984). Experiential learning: Experience as the source of learning and development. Englewood Cliffs, NJ: Prentice Hall.

Lebakeng, T. J. (2010). Discourse on indigenous knowledge systems, sustainable socio-economic development and the challenge of the academy in Africa. CODESRIA Bulletin, 1-2, 24-29.

Lee, L., \& Chen, P. (2014). Empowering Indigenous youth: Perspectives from a National Service Learning Program in Taiwan. International Indigenous Policy Journal, 5(3). Retrieved from: http://ir.lib.uwo.ca/iipj/vol5/iss3/4DOI: 10.18584/iipj.2014.5.3.4

Le Grange, L. (2007). The "theoretical foundations" of community service-learning: From taproots to rhizomes. Education as Change, 11(3), 3-13

Lewin, K. (1948). Resolving social conflicts: Selected papers on group dynamics. (G. Lewin, Ed.). New York: Harper \& Row.

Linda, N. B., Mtshali, N. G., \& Engelbrecht, C. (2013). Lived experiences of a community regarding its involvement in a university community-based education programme. Curationis, 36(1), 1-13. doi:10.4102/curaionis.v36i1.78.

MacGregor, K. \& Makoni, M. (2010, May 2). Universities must be citadels not silos. University World News. Retrieved from http://www.universityworldnews.com/ article.php?story $=20100502103801345$

McIntosh, P. (1988). White privilege and male privilege: A personal account of coming to see correspondences through work in women's studies (Working paper no. 189). Wellesley, MA: Wellesley College, Center for Research on Women. 
Magutu, P. O., Mbeche, I. M., Nyaoga, R. B., Nyaanga, R., \& Ombato, T. O. (2010). Quality management practices in Kenyan educational institutions: The case of the University of Nairobi. African Journal of Business and Management, 1(1), 14-28.

Mahlomaholo, S., \& Matobako, T. (2006). Service learning in South Africa held terminally captive by legacies of the past. Alternation Journal, 13(1).

McMillan, J., \& Stanton, T. K. (2014). "Learning service" in international contexts: Partnership-based service-learning and research in Cape Town, South Africa. Michigan Journal of Community Service Learning, 21(1), 64-78.

Meda, S. G. (2013). Single mothers of Nairobi: Rural-urban migration and the transformation of gender roles and family relations in Kenya. Urban People, 15(2), 279-307.

Mezirow, J. (1990). Fostering critical reflection in adulthood: A guide to transformative and emancipatory learning. San Francisco: Jossey-Bass.

Moon, J. (2004). A handbook of reflective and experiential learning: Theory and practice. London: Routledge Falmer.

Mouton, J., \& Wildshut, L. (2005). Service learning in South Africa: Lessons learnt through systematic evaluation. Acta Academica Supplementum, 2005(3), 116-150.

Munene, I. (2013). Our university: Ethnicity, higher education and the quest for state legitimacy in Kenya. High Education Policy, 26(1), 43-63. doi:10.1057/hep.2012.18

Mwenda, N. (2003). The challenges of education and development in post-colonial Kenya. Africa Development, 28, 3-4.

Naidoo, B., \& Devnarain, B. (2009). Service learning: Connecting higher education and civil society: Are we meeting the challenge? South African Journal of Higher Education, 23(5), 935-952.

Nathani Wane, N. (2000). Indigenous knowledge: Lessons from the elders. A Kenyan case study. In G. Dei, B. Hall, \& D. Rosenberg (Eds.), Indigenous knowledges in global contexts: Multiple readings of our world (pp. 54-69). Toronto: University of Toronto Press.

Ndiku, J. M., \& Muhavi, L. (2013). Government funding on access to secondary education in Kenya: Challenges and prospects. Journal of Educational Administration and Management, 1(1), 1-6.

Nganga, G. (2011, April 10). Kenya: Declining quality drives students overseas. University World News. Retrieved http://www.universityworldnews.com/article.php?story= 20110409153209817

Newton, J. M., \& Plummer, V. (2009). Using creativity to encourage reflection in undergraduate education. Reflective Practice, 10(1), 67-76. doi:10.1080/14623940802652821

Njue, J. R. M., Rombo, D. O., \& Ngige, L.W. (2007). Family strengths and challenges in Kenya. In J. Defrain \& S. Assay (Eds), Strong families around the world: Strengths-based research and perspectives (pp. 47-70). New York: Haworth.

Nyangau, J.Z. (2014). Higher education for economic growth in Kenya. FIRE: Forum for International Research in Education, 1(1) article 3.

Oanda, I. O., \& Jowi, J. (2012). University expansion and the challenges to social development in Kenya: Dilemmas and pitfalls. Journal of Higher Education in Africa, 10(1), 49-71.

O’Brien, F. (2005). Grounding service learning in South Africa. Acta Academica Supplementum, 3, 6598.

Odhiambo, G. O. (2014) Quality assurance for public higher education: Context, strategies and challenges in Kenya. Higher Education Research and Development, 33(5), 978-991, doi:10.1080/07294360.2014.890578

Opiyo-Newa, E. (2012). Assessing the internship program in universities: Case study of United States International University. Journal of Language, Technology and Entrepreneurship in Africa, 3(2), 112-119.

Osman, R., \& Castle, J. (2006). Theorising service learning in higher education in South Africa. Perspectives in Education, 24(3), 63-70.

Owuor, J. A. (2007). Integrating African indigenous knowledge in Kenya's formal education system: The potential for sustainable development. Journal of Contemporary Issues in Education, 2(2), 21-37. 
Permaul, J. S. (2009). Theoretical bases for service-learning: Implications for program design and effectiveness. New Horizons in Education, 57(3), 1-7.

Preece, J. (2016). Negotiating service learning through community engagement: Adaptive leadership, knowledge, dialogue and power. Education as Change 20(1), 104-125. doi:10.17159/1947$9417 / 2016 / 562$

Roos, V., Temane, Q. M., Davis, L., Prinsloo, C. E., Kritzinger, A., Naudé, E., \& Wessels, J. C. (2005). Service learning in a community context: Learners' perceptions of a challenging training paradigm. South African Journal of Psychology, 35(4), 703-716.

Stanton, T. K. \& Erasmus, M. A. (2013). Inside out, outside in: A comparative analysis of servicelearning's development in the United States and South Africa. Journal of Higher Education Outreach and Engagement, 17(1), 61-94.

Schön, D. (1987). Educating the reflective practitioner. San Francisco: Jossey-Bass.

Semali, L. (1999). Community as classroom: Dilemmas of valuing African Indigenous literacy in education. International Review of Education, 45(3/4), 305-319.

Sharpe, E. K., \& Dear, S. (2013). Points of discomfort: Reflections on power and partnerships in international service-learning. Michigan Journal of Community Service Learning, 19(2), 49-57. Retrieved from http://hdl.handle.net/2027/spo.3239521.0019.204

Simmons, M., \& Dei, J.S. (2012). Reframing anti-colonial theory for the diasporic context. Postcolonial Directions in Education, 1(1), 67-99. Retrieved from http://www.um.edu.mt/pde/index.php/pde1/article/download/9/28

Simons, L., Fehr, L., Blank, N., Connell, H., Georganas, D., Fernandez, D., \& Peterson, V. (2012). Lessons learned from experiential learning: What do students learn from a practicum/internship? International Journal of Teaching and Learning in Higher Education, 24(3), 325-334.

Smith, L. T. (1999). Decolonizing methodologies: Research and indigenous peoples. Dunedin, New Zealand: Zed Books.

Smith, L. T. (2014). Colonizing knowledges. In R. Maaka \& C. Andersen (Eds.), The Indigenous experience: Global perspectives (pp. 91-113). Toronto, ON: Canadian Scholars Press.

Smith, M. K. (2011). Donald Schön: Learning, reflection and change. Encyclopedia of Informal Education. Retrieved from http://infed.org/mobi/donald-schon-learning-reflection-change

Swaner, L. E. (2012). The theories, contexts and multiple pedagogies of engaged learning: What succeeds and why? In D. Harward (Ed.), Transforming undergraduate education: Theory that compels and practices that succeed (pp. 73-89). Lanham, MD: Rowman \& Littlefield.

Thaman, K. H. (2003). Decolonizing Pacific studies: Indigenous perspectives, knowledge, and wisdom in higher education. The Contemporary Pacific, 15(1), 1-17.

Thomson, A. M., Smith-Tolken A. R., Naidoo, A.V., \& Bringle, R. G. (2011). Service learning and community engagement: A comparison of three national contexts. Voluntas. 22, 214-237. doi:10.1007/s11266-010-9133-9

Tonkin, H. (2011). A research agenda for international service learning. In R. Bringle, J. Hatcher, \& S. Jones (Eds), International service learning (pp.191-224). Sterling, VA: Stylus Publishing.

Truth and Reconciliation Commission of Canada. (2015). Honouring the truth, reconciling for the future: Summary of the final report of the Truth and Reconciliation Commission of Canada. Retrieved from http://www.trc.ca/websites/trcinstitution/File/2015/Findings/ Exec_Summary_2015_05_31_web_o.pdf

Tumuti, D., Mule, L.W., Gecaga, M., \& Manguriu, D. G. (2013). Enhancing graduate employability through community engagement: A case study of students' community service at Kenyatta University. Journal of Administrative Sciences and Policy Studies, 1(1), 1-14.

United Nations. (2015). Sustainable development goals. Retrieved from https://sustainabledevelopment.un.org/topics 
Universities Australia. (2012). National best practice framework for Indigenous cultural competency in Australian universities. Retrieved from https://www.universitiesaustralia.edu.au/uni-participationquality/Indigenous-Higher-Education/Indigenous-Cultural-Compet\#.WeKg2ltSypo

Universities Canada. (2015). Universities Canada principles on Indigenous education. Retrieved from https://www.univcan.ca/media-room/media-releases/universities-canada-principles-onindigenous-education/

Universities Canada. (2016). Co-ops and internships: Providing students with career-boosting learning experiences. Retrieved from http://www.univcan.ca/priorities/co-ops-internships

VanLeeuwen, C. A., Kathuri-Ogola, L., Kabaria Muriithi, J., Ndayla, P., Kieru, J., \& Weeks, L. E. (2015). An evidence-based approach to enhancing Kenyan university student training and preparation for professional practice. International Development Research Centre project number: 10710800020503-026. Retrieved from http://hdl.handle.net/10625/54556

VanLeeuwen, C. A., Kathuri-Ogola, L., Kabaria Muriithi, J., \& Weeks, L. E. (in press). An evidencebased professional practice course for practicum students at a Kenyan university. Family and Consumer Sciences Research Journal.

van Wyk, J-A, \& Daniels, F. (2004). An integrated mentoring strategy for service learning in higher education. South African Journal of Higher Education, 18(2), 359-370.

wa Thiong'o, N. (1981). Decolonizing the mind: The politics of language in African literature. Portsmouth, UK: Heinemann Educational.

Waruru, M. (2015, May 15). Universities ordered to stop non-degree courses. University World News. Retrieved from http://www.universityworldnews.com/article.php?story= 20150514122242452

Wiesmann, U., Kiteme, B., \& Mwangi, Z. (2016). Socio-economic atlas of Kenya: Depicting the national population census by county and sub-location $\left(2^{\text {nd }}\right.$ revised ed $)$. Nairobi, Nanyuki, \& Bern: KNBS, CETRAD, CDE. doi:10.7892/boris.83693

Whitley, M. A. (2014). A draft conceptual framework of relevant theories to inform future rigorous research on student service-learning outcomes. Michigan Journal of Community Service Learning, 20(2), 19-40. Retrieved from http://hdl.handle.net/2027/spo.3239521.0020.202

Woolman, D. C. (2001). Educational reconstruction and postcolonial curriculum development: A comparative study of four African countries. International Education Journal, 2(5), 27-46.

Xing, J., \& Ka Ma, C. H. (2010). Service-learning in Asia: Curricular models and practices. Hong Kong: Hong Kong University Press.

Zembylas, M. (2015). "Pedagogy of discomfort" and its ethical implications: The tensions of ethical violence in social justice education. Ethics and Education, 10(2), 163-174. doi:10.1080/17449642.2015.1039274

Zlotkowski, E. (1998). Successful service-learning programs: New models of excellence in higher education. Bolton, MA: Anker Publishing. 
